\title{
The Knowledge of Leaders About Basic Cooperative Principles as a Key Factor for Agricultural Cooperatives Business Performances' in Horo Guduru Wollega Zone, Ethiopia
}

\author{
Mr. Mosisa Deressa Lemmi \\ $\mathrm{PhD}$ Candidate, Ambo University, Institute of Cooperatives and Development Studies, \\ Cooperative Department
}

\begin{abstract}
The main objective of this study is 'to examine the knowledge of leaders about basic cooperative principles as a key factor for Agricultural cooperatives business performances'. The study covers 96 cooperative leaders and 192 individual members of cooperatives selected from 96 primary agricultural cooperatives. The study employed both quantitative and qualitative research approach to answer the research question. The data related the study was collected with the help of survey questionnaire, key informant interview and focus group discussion from the study participants. The pertinent data collected were analyzed with the help of descriptive statistics and inferential model called multiple regression models. Accordingly, the 16 basic cooperative principles have significant impact on the business performances of agricultural cooperatives at 0.05 significance level. So, the government and other community development partners should arrange continuous trainings on cooperative principles and its roles on business practicesto cooperative leaders to improve the effectiveness of Leadership in enhancing business performance of cooperatives, and leaders of cooperatives need to focus on basic cooperatives principles as key factor for success of business practices of the cooperatives. These actions will ensure the survival, productivity, improved living standard of the cooperatives members, competitiveness, and prosperity of cooperatives businesses. Keywords: business performance, board of directors, cooperatives, cooperative principles, leadership, members, multiple regressions
\end{abstract}

DOI: $10.7176 / \mathrm{JAAS} / 60-03$

Publication date: January $31^{\text {st }} 2020$

\section{Introduction}

As of the ICA (1995) states, cooperative is an autonomous association of persons united voluntarily to meet common social, economic, cultural needs and aspirations through a jointly owned and democratically controlled enterprise. This definition very closely relates to the essential principles of cooperatives. There are seven cooperative principles: voluntary and open membership, democratic member control, member's economic participation, autonomy and independency, education, training and information, cooperation among cooperatives and concern to the community.

Superior organizational performance is not a matter of luck. It is determined largely by the choices leaders make. Despite the long history of research on leadership, only recently have the organization behavior scholars started to single out strategic leadership as a focus of attention (Narayanan \& Zane, 2009: 380). Policy makers and donors have increasingly recognized the roles of cooperative enterprises in creating employment and income generation with the dual objective of enhancing economic growth and sustainable development (Beck and Levine, 2003, Evans 1987, Everett and Watson, 1998). To meet the desired objective of the organizations, there should strong leadership who can lead for that purpose. To achieve business success, most people think it is mostly because of the strategy that the business comes up with. Strategy is one part of a whole range of reasons but not the only reason for success. There are a lot of things that amount to the success of an organization, and leadership without a doubt is one of the main reasons for this success.

Leaders with a high commitment could be a key to the development of an environment that provides organizational effectiveness. Since effective leaders demonstrated to be predictive of attitudes and performance in organizations, the question raised regarding whether other leadership behaviors would also be predictive in the same way or not (Cascio, 2010).

According to Emana(2012), the leadership problems in agricultural cooperatives facing in Ethiopia summarized into the following important areas of concern: understanding the use of financial statements, leadership training, strategic planning, board/manager relations, legal responsibilities, and performance assessment. Koopman(2004) underlines that effective board of directors teamed up with qualified professional management are essential for success of the cooperative. Therefore, this study isdeals about the effect of leadership on agricultural cooperatives business performance in HoroGuduruWollega zones of oromia regional state, Ethiopia. The specific objective of this study is 'to examine the knowledge of leaders about basic cooperative principles as a key factor for Agricultural cooperatives business performances'. 


\section{Literature Review}

Leadership can be defined in different ways that it is hard to come up with a single working definition. Leadership is not just a person or group of people in a high position. Leadership is a process in which leader is indulged in various activities to achieve any goal. Leadership refers to the behavior/ attitude of a leader to collect and direct the individuals towards any goal. Leadership is a communication process of leader and individuals. So the effectiveness of an organization depends upon the effective leader and effective leader is that person who has an effective leadership style. Leadership is a very important factor for any organization or group. There are three famous ways in which we can describe leadership from different perspectives.

An effective leader adapts its leadership style to a group of persons of individuals to gain the best results from each one of them, among the best qualities are being a good listener, give straight directions, follow up the employee's activities, and solve conflicts, openness to create a productive atmosphere (Druskat, et al. 2003). Empowerment and effective leadership are related in the way that a good leader will want to delegate activities and rest responsibilities' upon his or her employees. A good leader will tend to build his or her employees commitment and abilities to the company in order to develop, and one way of doing this is by means of empowerment (Druskat, et al. 2003).

A successful institution is the shadow and projection of the personality of a leader that behind every successful cooperative there is a person of integrity, vision, driving interest, dedication and perseverance. A leader must have strong faith in the movement.

Informed leadership is the very basis of a cooperative movement. It is important that a leader must know the principles and philosophy of cooperation, business policies basic principles of accounting, elements of parliamentary procedures for conducting board and general meeting, etc. the cooperatives, therefore, have to pay sufficient attention in electing the ablest, efficient and enlightened leaders who have genuine and keen interest in the development of the cooperatives movement. Cooperatives are democratic institutions. The successful operation of cooperative democracy in cooperatives depends on the democratic leadership. A successful democratic leader is one who is able to behave appropriately, direct and guide properly, and provide freedom to all member patrons without any discrimination.

Leadership plays a crucial role in the commitment of the members of the cooperative. Previous success of cooperatives does not guarantee future success. This is partly because of the causal link that relates to the success of cooperatives to members' commitment. Members' commitment to the cooperative is influenced by the decisionmaking process adopted by the cooperative leaders (Fulton, 2008).According to Perry(2001) and Beaver (2003), poor leadership practices in businesses are the cause of many business failures. Gordon and Yukl(2004) advocated more research on leadership skills relevant to turbulent small business environments. (Beaver, 2003) examined records from 200 bankrupt of businesses, from which he concluded that the primary failure of the organizations was a lack of leadership knowledge and neglect by management.

\section{Research methodology}

This study was conducted on farmer's agricultural cooperative societies in HoroGuduruWollega zone of oromia regional state. This study were employed a concurrent mixed approach (quantitative and qualitative) approach due to the nature of the study. The researcher convinced that the design could be appropriate for this study, as it is inclusive, and appropriate for collecting both qualitative and quantitative data for the study purpose. The study employed Cross-Sectional survey research design and it is economical, allows comparison of the variables at only one point at particular time (Saunder, 2003), and allows exploring more detailed reality about the problem understudy through its qualitative data gathered via focus group discussion and key informants. The study data was collected from 96 leader respondents of sampled agricultural cooperatives and 192 individual members of the cooperatives. In general, the total sample size of the study was 288 respondents. The collected data through different instruments were analyzed with the help of descriptive statistics and inferential model called multiple regression models.

\section{Data analysis and presentations}

The populations of this study were 288 , which mean 96 of them were leaders of the sampled primary agricultural cooperative societies and 192 of them were active individual members of the sampled primary cooperative societies from ChaffeBulluk and Haragufarmers' cooperative union. All of them are leaders and members of Primary agriculturalCooperative societies.

Knowledge of leaders about basic cooperative principles as a key factor for cooperative business performance

majority $(57.3 \%)$ of leader respondents were agree with that leaders of the cooperative societies have the knowledge of open membership as a cooperative principles to practice in their leadership practices and about $(14.6 \%)$ of them were strongly agree that leaders have the knowledge of open membership principle. The rest $(28 \%)$ of the respondents were opined as undecided, disagree and strongly disagree with leader's knowledge of 
open membership cooperative principles. As it is seen from the analysis of this investigation, there is a knowledge gap among some leaders of the cooperatives about open membership as basic cooperative principles to lead the cooperatives towards better performances.

Regarding leaders knowledge about voluntary membership principle, majority (44.3\%), (10.4\%) and (4.2\%) of them were opined as undecided, disagree and strongly disagree about their knowledge of voluntary membership principle to practice in their cooperative society while only the rest $(24 \%)$ and $(16.7 \%)$ of them were agree and strongly agree with the issue respectively. As the result of analysis reveals, most leaders of cooperative societies don't have required knowledge about voluntarily membership principle to apply in the leadership of their cooperative societies.

Regarding leaders knowledge of cooperative Members democratic control of their capital, majority (58.3\%) and $(21.9 \%)$ of them were opined as agree and strongly agree, while the rest $(13.5 \%)$ and $(6.3 \%)$ of them were opined as undecided and disagree with leaders knowledge of members democratic control of their capital in their cooperatives. As the result of analysis shows, there is a knowledge gap with leaders of the cooperatives about democratic management of the capital of the cooperatives with its patrons.

Regarding democratic election (one man, one vote) of the cooperatives, majority (49\%) and (20.8\%) of the leader respondents agree and strongly agree with leaders knowledge about democratic election (one man, one vote) principle to exercise in their cooperatives while the rest $(12.5 \%),(9.4 \%)$ and $(8.3 \%)$ of them were opined as undecided, disagree and strongly disagree about their knowledge of democratic decision making. About (31.3\%), $(17.7 \%)$ and $(4.2 \%)$ of leader respondents opined as undecided, disagree and strongly disagree about leaders knowledge of Members right to fire committee if needed in the cooperatives. As the result of analysis indicates, leaders of the cooperatives have knowledge gap of democratic election practices and members right to fire committee of cooperatives if needed for proper management of the cooperatives and their business.

\section{Descriptive statistics of leaders knowledge of Basic Cooperatives Principles}

Table 4-3.2 illustrates that the respondents knowledge of the basic cooperatives principles (BCP) to practice in the successful performance of the cooperatives business. Leaders could achieve the goal of cooperatives in implementing the basic cooperatives principles. The medium mean score indicates that the cooperative leaders have the knowledge of open membership principle and voluntary membership principle $(X=3.96$ and 3.75$)$. Leaders knowledge of decision making in cooperatives are based on one man one vote principles and members democratically control their capital have the mean score of $(X=3.65$ and 3.39) respectively. In cooperative business organization, cooperative leaders have the knowledge of members right of freely electing and firing the committee and have required autonomy and independency to perform their activities ( $T=3.30,3.28$ and 3.14).

The other is about leader's knowledge about cooperative local horizontal cooperation and regional vertical cooperation have the mean score of $(X=3.15$ and 3.38) respectively. The remaining seven variables have less than 3.0 mean values about the leader's knowledge of basic principles of cooperatives. This result indicated that leaders of cooperative society have not good understanding about cooperative principles as a key factor for cooperative success. Moreover, key informants of the study also explained asLeaders of primary cooperative society are farmers who have little formal education and knowledge but they elected from the farmer members by their relative better local knowledge and their innate leadership qualities. Leaders have no cooperative principles and values knowledge to lead their cooperatives. Therefore, to solve this problem the union has been trying some remedial activities like training to leaders but it is very less because of budget scarcity and less consideration given to such knowledge. In addition to these, focus group discussion (FGD) of the study described leaders of primary cooperative society lacks understanding of basic cooperative principles and leading their cooperatives in traditional form.

The mean scores of the variable of business performance of cooperatives (BP). This construct are about how the leaders perceive the performances of cooperatives business. The items of the variable more focus on financial, production and marketing performances of the cooperatives businesses. The mean perception values of the respondents to the business performances practices in cooperatives organizations found to be moderately ranging from $X=3.04$ to $X=3.76$ for ten mean values. The rest five mean scores describe low mean values ranging from $X=2.70$ to $X=2.84$. Therefore, the overall leaders' perception to financial, market and production performance of the cooperative business performance were low. 
Model Summary

\begin{tabular}{|l|r|r|r|r|r|r|r|r|r|}
\hline Model & $\mathrm{R}$ & \multirow{2}{*}{$\mathrm{R}$} & Adjusted & Std. Error of & \multicolumn{5}{|c|}{ Change Statistics } \\
\cline { 7 - 10 } & & Square & $\begin{array}{c}\mathrm{R} \\
\text { Square }\end{array}$ & the Estimate & $\begin{array}{c}\text { R Square } \\
\text { Change }\end{array}$ & F Change & df1 & df2 & $\begin{array}{c}\text { Sig. F } \\
\text { Change }\end{array}$ \\
\hline 1 & $.807^{\mathrm{a}}$ & .651 & .375 & .263 & .651 & 2.356 & 42 & 53 & .002 \\
\hline
\end{tabular}

a. Predictors: (Constant), Basic cooperative principles

b. Dependent Variable: Business Performance

In this case the value of $\mathrm{R} 2=.651$ and this means that the model explains $65.1 \%$ of the variance in dependent variable (BP). Several residual statistics can be used to assess the influence of a particular case. If a case does not exert a large influence over the model, the adjusted predicted value is very similar to the predicted value when the case is included (Field 2009).

ANOVA ${ }^{\mathrm{a}}$

\begin{tabular}{|ll|l|l|l|l|l|}
\hline Model & & Sum of Squares & df & Mean Square & F & Sig. \\
\hline \multirow{3}{*}{1} & Regression & 3.281 & 16 & .205 & 2.244 & $.010^{\mathrm{b}}$ \\
& Residual & 7.219 & 79 & .091 & & \\
& Total & 10.500 & 95 & & & \\
\hline
\end{tabular}

a. Dependent Variable: Business performance

b. Predictors: (Constant), the coops participate on community development, coop render education to publics, the coop is socially concerned, members fire the committee when needed, independency of cooperatives, members develop the capital of their coops, dividend is shared for members as thierpartici, cooperative membership is open for all, local horizontal partnership, members paid fixed interest on thiercaptal, regional vertical partnership b/n coops, Membership is voluntary in coops, member \& committee education and training, coop members democratically control the capita, Autonomy of coop members, one man, one vote

The above ANOVA table reveals us that, the "F" statistic for the model has a significance level of 0.00 . This entails that at least one of the correlation between each of the independent variables are not equal to zero.

Coefficient

\begin{tabular}{|c|c|c|c|c|c|}
\hline \multirow[t]{2}{*}{ Model } & \multicolumn{2}{|c|}{$\begin{array}{c}\text { Unstandardized } \\
\text { Coefficients }\end{array}$} & \multirow{2}{*}{$\begin{array}{c}\begin{array}{c}\text { Standardized } \\
\text { Coefficients }\end{array} \\
\text { Beta } \\
\end{array}$} & \multirow[t]{2}{*}{$\mathbf{T}$} & \multirow[t]{2}{*}{ Sig. } \\
\hline & B & Std. Error & & & \\
\hline (Constant) & 1.054 & .306 & & 3.440 & 0.001 \\
\hline cooperative membership is open for all & -.152 & .059 & -.358 & -2.564 & 0.012 \\
\hline Membership is voluntary in coops & .056 & .056 & .147 & 1.007 & 0.017 \\
\hline $\begin{array}{l}\text { coop members democratically control } \\
\text { the capita }\end{array}$ & -.042 & .049 & -.130 & -.873 & 0.085 \\
\hline one man, one vote & .118 & .045 & .412 & 2.606 & 0.011 \\
\hline $\begin{array}{l}\text { members fire the committee when } \\
\text { needed }\end{array}$ & -.164 & .049 & -.496 & -3.308 & 0.001 \\
\hline $\begin{array}{l}\text { devidend is shared for members as } \\
\text { thierpartici }\end{array}$ & .071 & .043 & .197 & 1.650 & 0.003 \\
\hline $\begin{array}{l}\text { members develop the capital of their } \\
\text { coops }\end{array}$ & .004 & .058 & .008 & .062 & 0.051 \\
\hline $\begin{array}{l}\text { members paid fixed interest on } \\
\text { thiercaptal }\end{array}$ & .055 & .053 & .133 & 1.033 & 0.005 \\
\hline Aoutonomy of coop members & .090 & .058 & .232 & 1.564 & 0.022 \\
\hline independency of cooperatives & -.053 & .044 & -.168 & -1.202 & 0.033 \\
\hline $\begin{array}{l}\text { member \& committee education and } \\
\text { training }\end{array}$ & -.066 & .046 & -.208 & -1.454 & 0.050 \\
\hline coop render education to publics & -.020 & .058 & -.042 & -.341 & 0.034 \\
\hline local horizontal partnership & .015 & .045 & .040 & .331 & 0.042 \\
\hline regional vertical partnership $\mathrm{b} / \mathrm{n}$ coops & .080 & .049 & .217 & 1.629 & 0.007 \\
\hline the coop is socially concerned & .019 & .050 & .058 & .390 & 0.007 \\
\hline $\begin{array}{l}\text { the coops participate on community } \\
\text { devt }\end{array}$ & .036 & .043 & .098 & .831 & 0.009 \\
\hline
\end{tabular}

a. Dependent variable: business performance 
All variables of the basic cooperative principles are significant at 0.05 significant levels. This result entails us that leader's knowledge of cooperative principles has significant impact on business performances of the cooperative societies in the study area.

\section{Conclusions}

As the results of analysis reveals, cooperative leader's knowledge of cooperative principle as a key factor for cooperative business success is a key problem affecting business performances of agricultural cooperatives in the study area. The government and other community development partners should arrange trainings for leaders to improve the effectiveness of Leadership in enhancing business performance of cooperatives, and leaders of cooperatives need to focus on basic cooperatives principles as key factor for success of business practices of the cooperatives. These actions will ensure the survival, productivity, improved living standard of the cooperatives members, competitiveness, and prosperity of cooperatives businesses.

\section{Acknowledgement}

First and foremost, Glory to Almighty GOD who helped me to carry all the burdens throughout my study and reach completion of the dissertation. Completing a doctoral degree requires a great deal of support and assistance. To those individuals whose time, concern and efforts were given on my behalf, my deepest appreciation is extended.

I would like to thank my supervisor, Professor S.Nakkiran (PhD), for his unwavering support, guidance, and mentoring throughout this life-changing experience. Undoubtedly, my supervisor and committees was the cornerstone of the success of this dissertation. I also want to thank too the study interviewees for their open, honest, and frank answers, and for the considerable time and insight they dedicated despite their already full schedules.

I am deeply indebted to the University of Ambo, who provided generous Research funding in cooperation with Ministry of education (MOE) for successful completion of the study. I also need to acknowledge Wollega University for the scholarship opportunity given for me during all my study period. My thanks also goes to Federal Cooperative Agency (FCA) for their funding to this dissertation research and their contribution is great in successful completion of this study.

I also need to acknowledge my parents for their relentless teachings on the value of words of GOD, hard work, and discipline. My father, who passed away when I was a child of 2 years old, and my mother, raised me with the clear conviction that education is the best vehicle for human development. This dissertation is a testament to their lifelong efforts. Lastly, my greatest thank is to my wife, MeseretAmanu, and my son, SegniMosisa, and my daughters, JituMosisa, MilkiMosisa for their patience, support, and understanding throughout days, evenings, weekends, and vacations for many years. Meseret, my beloved wife beside her very huge burden of house works and caring to children, she contributed a lot to this dissertation. This dissertation is dedicated to both of them.

\section{REFERENCE}

(1) Adrain, J.L. and Green, T.W. 2001. 'Agricultural Cooperatives Managers and the Business Environment'. Journal of Agribusiness, 19(1): 17-33.

(2) Birchall J (2005). Co-operative principles ten years on. International Cooperative Alliance, Issue 2, 98(2):4563. Available from :< http://www.ica.coop/> [Accessed on September 1, 2016].

(3) Cascio, Robert, Babu John Mariadoss and NacefMouri (2010), "The Impact of Management Commitment Alignment on Salesperson' Adoption of Sales Force Automation Technologies: An Empirical Investigation," Industrial Marketing Management, 39, 1088-1096.

(4) Chibanda, Ortmann\&LyneAgrekon, 2009. 'Institutional and governance factors influencing the performance of selected smallholder agricultural cooperatives in KwaZulu-Natal',Agrekon, Vol 48, No 3

(5) Coldwell, D., and Herbst, F. 2004. Business Research. Cape town, South Africa. Juta and Co.Ltd

(6) Cook, M.L. 1994. 'The Role of Management Behavior in Agricultural Cooperatives', Journal of Agricultural Cooperation, 9: 42-58.

(7) Cook, P.2006. 'Management and leadership development: making it works', industrial and commercial training, 38(1):49-52.

(8) Daft, R.L. 2011. The leadership experience. 5th edition. Cincinnati, Ohio: Cengage Learning South-Western.

(9) Daft, R.L. 2011. The leadership experience. 5th edition. Cincinnati, Ohio: Cengage Learning Southwestern.

(10)Emana, B. 2012. Cooperatives Movement in Ethiopia. Uganda. Available fromhttp://www.fes

(11)Erkutlu, H., 2008. 'The impact of transformational leadership on organizational and leadership effectiveness', Journal of management development, 27 (7):708-726.

(12)Ethiopia. Federal Cooperatives Agency.2016.Cooperative.P019787.Addis Ababa: Federal Cooperatives Agency.

(13)Folsom, J. 2003. Measuring the Economic Impact of Cooperatives in Minnesota. RBS Research Report 200. USDA Rural Business-Cooperative Service: Washington, D.C. 23.

(14)ForgácsCsaba. 2008. 'Leadership and Importance of Social Capital in Cooperatives during Transition: A Case 
Study of Two Cooperatives', Journal of Rural Cooperation, 36 (1): 57-72.

(15)Fulton, M. and K. Giannakas 2007. 'Agency and Leadership in Cooperatives', in K. Karantininis and J. Nilsson (eds), Vertical Markets and Cooperative Hierarchies, pp. 93-113. Netherlands: Springer. doi: 10.1007/1-4020-5543-0_6

(16)Horner, M. 1997. 'Leadership theory: Past, present and future', Team performance Management, 3(4): 270287.

(17) ICA, (1995), Cooperative Identity, Values and Principles. ICA.Geneva

(18) Jackson, L.S.2009. Research Methods and Statistics.3rd ed. USA: wadsworthcengage learning

(19) James A. F. Stoner, R. Edward Freeman and Daniel R. Gilbert, Jr. (1995).Management, $6^{\text {th }}$ edition

(20) Jeremy .M, Melinde .C \& Ciller V. (2012). Perceived leadership style and employee

(21) Karamat. (2013): Impact of Leadership on Organizational Performance, Research paper, D\&R Cambric Communication.

(22) Kenkel, P., \& Park, J. (2011). Theme Overview: Critical Issues for Agricultural Cooperatives, 26(3)

(23) Kieu, H. Q. (2010). Leadership Styles and Organizational Performance: A Predictive Analysis: ERIC.

(24)Kirkpatrick, S.A. and Locke, E.A. (1991), “Do traits matter?” Executive, Vol. 5, pp. 48-60. Kline, R. (2005), The Principles and Practices of Structural Equation Modeling, The Guilford Press, New York, NY.

(25)Kodama, Y.2007. 'New Role of Cooperatives in Ethiopia', African Study Monographs, 35: 87108.

(26)Kothari, C.R. 2004. Research Methodology; Method and Techniques. 2nded. New Delhi: new age international (p) limited, publishers.

(27) M. Karthikeyen. (2013), Determinants of Cooperative Leadership for Social Innovation: An Assessment of Selected MPCSs in Oromia Region of Ethiopia, Malaysian Journal of Cooperative, Vol. 9, 47-75

(28) McCartney, W. and Campbell, C. 2005. 'Leadership management, and derailment', Leadership \& Organizational Development Journal, 27(3): 190-202.

(29) Michael. A. (2010). Leadership style and organizational impact. Retrieved from: http/ www.ala apa.org.

(30) Mooi, E. and Sarstedit, M. 2011. A concise Guide to Market Research;The Process, Data, and Methods Using IBM SPSS Statistics. Springer Heidelberg Dordrecht London New York.

(31) Najamuddeen, G. Abubakar, B.Z. Kebbe,M.G,Magaji, A.S. and Ukashatu S. (2012), Role of CooperativeSocieties in Community Development in Sokoto Metropolis, Sokoto State

(32) Narayanan, V.K. \& Zane, L.J. 2009. Inventing a future for strategic leadership: phenomenal variety and epistemic opportunities. Journal of Strategy and Management, 2(4): 380-404.

(33) S. Nakkiran (2002), A Treatise on Co-operative Management, Fourth Rev. Ed., India

(34) Saunders,. 2003. Research Methods for Business Students, $5^{\text {th }}$ Ed. Harlow, England. Pearson Education Ltd

(35) Stephen P. Robbins and Mary Coulter, (2005).Management, $8^{\text {th }}$ edition, India

(36) Steven L. Mc Shane and Mary Ann Von Glinow, (2000).Organizational behavior,

(37) Svensson, G. and Wood, G.2006. 'Sustainable components of leadership effectiveness in Organizational performance', Journal of Management Development, 5(6):522-34. 